\title{
Perception of Learners Towards Monolingualism, Bilingualism and Multi-Language Learning
}

\author{
Halil Küçükler ${ }^{1} \&$ Irfan Tosuncuoglu $^{2}$ \\ ${ }^{1}$ Balıkesir University, Turkey \\ ${ }^{2}$ Karabük University, Turkey \\ Correspondence: Halil Küçükler, Balıkesir University, Turkey.
}

Received: October 21, 2018 Accepted: November 27, 2018 Online Published: November 29, 2018

doi: $10.5539 /$ elt.v11n12p221

URL: https://doi.org/10.5539/elt.v11n12p221

\begin{abstract}
Monolingualism is defined as state of having control over the use of one language. Bilingualism means having control over the use of two languages and multi-lingualism is defined having control over the use of more than two languages. The purpose of this study is to make a comparison of the learners' perceptions towards monolingualism, bilingualism and multilingualism. The study was done in year of 2018. The study was done by applying questionnaires to the preparation faculty at International Hoca Ahmet Yesewi University and Balıkesir University respondents. Totally, there are 196 respondents from Yesewi University and 172 respondents from Ballkesir University. Both BAU and AYU respondents disagree that people who speak a language best are those who know one language rather than two or more. They also both agree that learner should try not to use their first language while learning a new language. Both BAU and AYU respondents agree that learning another language is important because it allows them to be more at ease with people who speaks that language. However, AYU respondents have a stronger positive attitude than BAU respondents.
\end{abstract}

Keywords: monolingualism, bilingualism, multilingualism, foreign language learning

\section{Introduction}

Monolingualism is the ability of a person to speak in one language. In second language learning, learner learns a language other than his/her native/first language(s). First language is normally a native language and the second is an acquired foreign language (Jean-Mark, 2015). Bilingualism is the ability of a person to speak in two languages. In a bilingual community, children can learn two languages simultaneously, these two languages can be viewed as their native/first languages, they are bilingual learners. Multi-language learning means using or having the ability to use several languages. Learners have varied perception towards multi-language learning. This is in regard to the benefits or the shortcomings that are associated with multi-language learning. This paper will analyze a questionnaire from a research carried out in Balıkesir University (BAU) and Ahmet Yesewi University (AYU) to determine if there is a relationship between second language and attitude towards language learning. This paper will also establish if multi-language learning has any effects on attitude towards learning language learning and if there is a difference between the attitudes of homogeneous and heterogeneous groups of multi-language learners.

Attitude towards language learning is the overall disposition of a person's thoughts, feelings and actions towards learning language (Riano, 1990). Also, motivation as addition important factor of Language learning and it is a significant factor of language according to Gardner and Lambert (Gardner and Lambert, 1972; cited in Tosuncuoglu, 2017). Motivation towards leaning a second language can be classified into three components. They are; ideal self motivation, ought to proponent and the second language learning experience (Erika-Mária \& Zsuzsanna, 2016). In this research the three motivations were framed as the opinions about second language learning, type of and attitudes toward second language learning. These motivations formed the basis of research and the consequent results and discussions presented below.

The study is about perception of learners towards multi-lingualism at Hoca Ahmet Yesewi University. International Hoca Ahmet Yesewi University Turkish-Kazakh University is an international and autonomous mutual state university of the Republics of Turkey and Kazakstan. The mission of the university is to educate students from Turkish speaking states and Communities and to become competitive university as the symbol of 
friendship and solidarity between Turkish States and Communities that perform education and research activities on international standards with scientific and technological research infrastructure and service understanding, symbol of friendship and solidarity between Turkish States and Communities and competitive. In Academic units, there are eight faculties such as Faculty of Social Sciences, Faculty of Humanity, Faculty of Language, Faculty of Science, Faculty of Engineering, Faculty of Art, Faculty of Medicine, School of Foreign Languages. In Research Institute, there are seven research institutes such as Turkology Research Institutes, Ecology Research Institute, Eurasian Research Institute, Museum and Archaeology Research Institute, Health Sciences Research Institute, Natural Sciences Research Institute, Scientific Research Center named After Yesewi. Besides formal education, there are two different distance education programs such as TURTEP for Turkish master studies and KAZTEP for Kazak master studies.

The study was done by administering questionnaires in the English Department at the Faculty of Language Preparation at International Hoca Ahmet Yesewi University. The faculty is so important for students who wants to learn multi-languages such as Kazakh, Turkish, Russian and English. Every year students from different countries study in the faculty. These are; Turkey, Karakalpakstan, Uzbekistan, Tajikistan, Turkmenistan, Mongolia, China, Kirgizstan etc. The study analyses bilingualism and multi-language learning reflections at Hoca Ahmet Yesewi University. (www.ayu.edu.tr.)

\section{Methodology}

\subsection{Research Design}

The study adopted descriptive research design. This research design basically refers a research designed to describe the target population. It involves collection of quantitative information that can tabulated along a continuum in numerical form. This means collecting data that describes the issue under investigation and then organizes, tabulates, and describes the issue. The data collected was mainly descriptive data. Survey research approach was employed to collect data from the sample population.

\subsection{Participants}

The study was carried out during 2018 academic year for students in the English Deaprtment at the Faculty of Language Preparation at Yesewi University and first year students at the Balıkesir University. There were 196 prep-class students in Hoca Ahmet Yesevi international Turk-Kazakh University and 172 first year students from Balıkesir University students. Of the students that were interviewed, some were monolingual and some were multi-language learners. Both the monolingual and multi-language students had varying attitudes about second language learning.

\subsection{Research Instrument}

The research instrument for this study was adapted from the Language Attitudes Questionnaire (LAQ) developed by Vivian Cook (2001) (qtd. in Yüksek). The language Attitudes Questionnaire included the items about opinions about second language learning and type of motivation. The instrument has been found to have good internal reliability. The survey items have acceptable Cronbach's alpha values though some items have been found show reliabilities level below Nunnally and Bernstein's (1994) criterion of acceptable alpha, which is at a $=.70$. This has however been attributed to the small number of items in the PLSPQ instrument and the function that each item serves.

\subsection{Data Collection}

Primary data was collected from participants using PLSPQ research instrument. The data from LAQ was analysed by Chi-square and Descriptive Statistics in the SPSS (Statistical Package for Social Sciences) Program. The questionnaires were distributed to the participants and collected from them after they had filled them. The responses were recorded in Ms Excel.

\subsection{Data Analysis}

Descriptive statistics were calculated in order to draw inferences. The descriptive statistics included frequencies and proportions or percentages. These were presented in graphical formats to show summaries of the data collected for particular survey items. The responses that were given by the students were compiled into percentages and documented. The results gotten are documented in the results data sheet. A discussion of the results is presented. 


\section{Research Results}

\subsection{General Statistical Results}

One statistical fact is that more than $50 \%$ of the population uses more than one language in their every day interaction. Over $60 \%$ of the population believes a second language gives them additional job opportunities. $50 \%$ of the population recognizes that they need to speak more than one language on a day to day basis. Only $36 \%$ of the population thinks that it is beneficial for all people to be speaking one language in the country. In issues of mental health, memory, psychological health and self identity, only $35 \%$ believes there is benefit of being more than a one language speaker. When it comes to cognitive abilities like memory, intelligence and open mindedness, more than $60 \%$ believe bilingualism plays a part. $60 \%$ of people feel that being fluent in the first language adds a sense of pride and identity.

\subsection{Detailed Results}

The research that was carried out in BAU and AYU respondents revealed some divergent views on second language learning. There are three main areas of interest that are analyzed in this paper. They are the opinions about second language learning, type of and attitudes toward second language learning. The results of the research that was carried out were analyzed and summarized in the tables below;

Table 1. Opinions about second language learning

\begin{tabular}{|c|c|c|c|c|c|}
\hline & \multicolumn{3}{|l|}{$\overline{B A U}$} & \multicolumn{2}{|l|}{$\overline{\mathrm{AYU}}$} \\
\hline & $\begin{array}{l}\text { The } \\
\text { Frequent } \\
\text { Response }\end{array}$ & Most & $\%$ & $\begin{array}{l}\text { The } \\
\text { Frequent } \\
\text { Response }\end{array}$ & $\%$ \\
\hline $\begin{array}{l}\text { 1- The people who speak a language best are those who } \\
\text { know only one language rather than two or more. }\end{array}$ & Disagree & & 39.8 & Disagree & 37.8 \\
\hline 2- Native speakers make the best language teachers. & Neutral & & 40.3 & Agree & 34.3 \\
\hline $\begin{array}{l}\text { 3- You should try not to use your first language while } \\
\text { you are learning another language. }\end{array}$ & Agree & & 36.2 & Agree & 28.5 \\
\hline $\begin{array}{l}\text { 4- It is important not to have an accent in another } \\
\text { language. }\end{array}$ & Neutral & & 42.1 & Agree & 36.6 \\
\hline $\begin{array}{l}\text { 5- Switching between languages in a conversation is } \\
\text { rude even if the other person knows both languages. }\end{array}$ & Agree & & 29.4 & Agree & 33.7 \\
\hline 6- Children learn second languages better than adults & Neutral & & 52.9 & Agree & 52.8 \\
\hline $\begin{array}{l}\text { 7- People who go to live in a new country should give } \\
\text { up their own language. }\end{array}$ & Agree & & 37.4 & Strongly Disagree & 39.0 \\
\hline $\begin{array}{l}\text { 8- It is difficult to learn a second language in a } \\
\text { classroom. }\end{array}$ & Neutral & & 27.8 & Disagree & 35.5 \\
\hline
\end{tabular}

\subsubsection{Opinions About Second Language Learning}

From the research carried out in BAU and AYU, the respondents have different opinions toward learning a second language. Both BAU and AYU disagree that people who speak a language best are those who know one language rather than two or more. They also both agree that learner should try not to use their first language while learning a new language. AYU agree that it is important to not have an accent in another language whereas BAU respondents are neutral. BAU agrees that people who live in a new country should give up their own language but AYU strongly disagrees. AYU disagrees that it is difficult to learn a new language in classroom but BAU is neutral.

\subsubsection{Type of Motivation}

Both BAU and AYU respondents agree that learning another language is important because it allows them to be more at ease with people who speaks that language. However, AYU has a stronger positive attitude than BAU. Most respondents agree that learning a new language will be beneficial in their career, they will be able to meet all kinds of people, they will become more knowledgeable, and they will be in a better position to acquire jobs. In addition, learning and speaking another language helps people take part more freely in the activities of other 
cultural group and also they will be more respected.

From the above findings it is apparent that people have different motivations that guide them in wanting to learn a new language. There is an agreement between monolinguals and bilinguals about some of the benefits of being bilingual. Both monolinguals and multi-linguals stand a chance of being better in life if one is a bilingual and not a monolingual. One inherent factor is that multi-linguals usually get better jobs than monolingual people (Salim \& Ekatrina, 2010). In the most prolific jobs, one is needed to be communicating with different stakeholders, some of whom have different languages. A second language is therefore normally a requirement. Sometimes, a second language is just an added advantage if two people are deemed to have the same qualifications. A bilingual person also has a larger variety of job options as opposed to a person who is monolingual (Salim \& Ekatrina, 2010). Opportunities could be domestic and could also be oversees for them.

Table 2. Type of motivation

\begin{tabular}{|c|c|c|c|c|}
\hline & \multicolumn{2}{|l|}{ BAU } & \multicolumn{2}{|l|}{ AYU } \\
\hline & $\begin{array}{l}\text { The Most } \\
\text { Frequent } \\
\text { Response }\end{array}$ & $\%$ & $\begin{array}{l}\text { The Most } \\
\text { Frequent } \\
\text { Response }\end{array}$ & $\%$ \\
\hline $\begin{array}{l}\text { 1- Speaking or learning another language is important to me } \\
\text { because it will allow me to be more at ease with people who } \\
\text { speak that language. }\end{array}$ & Agree & 40.4 & Strongly Agree & 62.0 \\
\hline $\begin{array}{l}\text { 2- Speaking or learning another language is important to me } \\
\text { only because I need it for my career. }\end{array}$ & Agree & 40.9 & Agree & 28.2 \\
\hline $\begin{array}{l}\text { 3- Speaking or learning another language is important to me } \\
\text { because I will be able to meet and to more kinds of people. }\end{array}$ & Agree & 39.9 & Strongly Agree & 52.1 \\
\hline $\begin{array}{l}\text { 4- Speaking or learning another language is important to me } \\
\text { because it will make me more knowledgeable. }\end{array}$ & Agree & 38.3 & Strongly Agree & 47.9 \\
\hline $\begin{array}{l}\text { 5- Speaking or learning another language is important to me } \\
\text { because I will be able to enjoy the films and books of the } \\
\text { people who speak it better. }\end{array}$ & Agree & 35.8 & Strongly Agree & 61.3 \\
\hline $\begin{array}{l}\text { 6- Speaking or learning another language is important to me } \\
\text { because I think it will someday be useful in getting a good } \\
\text { job. }\end{array}$ & Agree & 39.4 & Strongly Agree & 67.3 \\
\hline $\begin{array}{l}\text { 7- Speaking or learning another language is important to me } \\
\text { because I will be able to take part more freely in the } \\
\text { activities of other cultural groups. }\end{array}$ & Agree & 39.4 & Strongly Agree & 57.1 \\
\hline
\end{tabular}

\subsubsection{Attitude Towards Second Language Learning}

Both BAU and AYU reached a consensus that it is important to be able to speak more than one language. They both agreed that knowing two languages makes people cleverer and that all schools should teach children two languages. They also agreed people make more friends and earn more money if they speak two languages. However, AYU agreed more strongly than BAU.

Table 3. Attitudes toward second language learning

\begin{tabular}{lllll}
\hline & BAU & \multicolumn{2}{l}{ AYU } \\
\cline { 2 - 5 } & $\begin{array}{l}\text { The Most Frequent } \\
\text { Response }\end{array}$ & $\%$ & $\begin{array}{l}\text { The Most Frequent } \\
\text { Response }\end{array}$ \\
\hline 1- It is important to be able to speak two languages. & Agree & 52.2 & Strongly Agree & 52.4 \\
2- Knowing two languages makes people cleverer. & Agree & 30.9 & Strongly Agree & 49.4 \\
3- Being able to write in two languages is important. & Agree & 51.7 & Strongly Agree & 47.6 \\
4- All school in my country should teach pupils to & Agree & 49.8 & Strongly Agree & 41.0
\end{tabular}
speak in two languages. 
5- Children in my country should learn to read two Agree languages.

6- People who speak two languages can have more Agree friends than those who speak one language.

7- People may earn more money if they speak two Agree languages.

8-People know more if they speak two languages.
47.8 Strongly Agree

38.6

29.8 Strongly Agree

29.8 Strongly Agree

40.4

27.3 Strongly Agree

\section{Discussion and Explanation}

Opinions on multilingualism are divergent based on whether the respondent is a monolingual or a bilingual individual. This applies to the accrued benefits and the shortfalls of being bilingual (Krista \& Casey, 2013). However, there are some of opinions that are similar for both the bilingual and the monolingual respondents. Based on the research that was carried out in BAU and AYU, factual feelings and psychological and personal consideration on multi-lingualism, show that there is a relationship between multi-lingualism and attitude towards learning. The attitude towards learning based on multi-lingualism can be evaluated based on whether the students are immigrants or natives. From the above findings AYU strongly agrees that learning a second language is very beneficial. This shows that multi-lingualism strengthens the attitude of learning new language. It may be because multi-lingualism have experienced some of the benefits of knowing two languages.

This research echoes previous researches on the importance of multi-lingualism. Multi-lingual learning has its benefits. On a preparatory school level, the academic achievement is mostly focused on their development and increment of understanding such that the students can use their first language as a source for learning (Albany \& Vania, 2009). At the young age, they can develop a proficiency to know two languages at an early stage. Bilingual children can establish their first languages as well as their second language thus becoming interdependent. Additionally, a bilingual child is exposed to bilingual strategies that fully embrace the already existing knowledge and further enable them to interact with the contents better. In this case, bilingual education erases the idea of ignorance in the children from an early age as they are adapted to learn different concepts in both languages (Cummins, 2001).

At the preparatory level, the effectiveness of multi-lingualsim in the classroom exceeds expectations depending on the country. In countries that do not have English or a common language as their first language, the possibility of various languages being used is inevitable (Andrew, 1998). The schools in such states should consider adding the practices and policies in the curriculum. In such a case where the children speak more than one language, there should be a core curriculum that seeks to develop the self-esteem and identities of the children while fully embracing their first language. For instance, in Finland, they have developed a system that takes into account the cultural background through a preparatory instruction for the newbie and a second language instruction for the transitioning students (Suni \& Latomaa, 2012).

In the social sphere, physiological sphere and personal sphere, there is a relationship between multi-lingualism and attitude towards learning. However, the attitude split between the multi-linguals and the monolinguals. Bilinguals are more optimistic about learning a second language as opposed to monolinguals (Albany \& Vania, 2009). Heterogeneous groups thrive in the diversity of bilingualism. On the other hand, the Homogeneous groups are skeptical of their position in the face of bilingualism (Lydiah, 2015).

\section{Conclusion}

As seen in the above results, attitudes influence the reception of a second language by learners, (Eshghinejad, 2016). The above research was quantitative and qualitative in nature. Central to the research was the emotional sentiment of the respondents. As Inal, Evin, \& Saracaloğlu (2005) note, the emotional connection with a language is vital to acquisition of a second language. The questions that were asked had strong relationship with the attitude of the respondents, which is a component of the emotional component. Though the responses that were given had differences based on the target group, there is a strong correlation between attitude and second language learning.

Even though respondents had different opinions on multi-lingualism. The most predominant attitude towards second language and multi-language learning is positive. Both immigrants and native have a positive attitude towards learning a new language and believe its benefits to them (Shams, 2008). Bilingual respondents portrayed stronger positive attitude. Bilingualism has a positive effect on learning a new language. This research aligns with most past research that finds learning a new language beneficial. A research by Hoover states that students 
that are bilingual have greater cognitive abilities than those students with only one language (Hoover, 1982). The benefits of bilingualism are manifested in the social sphere, the psychological sphere and also at a personal level.

\section{References}

Ahmet Yesewi University. (2018). Retrieved November 12, from http://www.ayu.edu.tr

Cummins, J. (2001). Bilingual children's mother tongue: Why is it important for education? Sprogforum, 19, $15-20$.

Erika, M., \& Zsuzsanna, D. (2016). Language Attitudes, Language Learning, Experiences and Individual Strategies What Does School Offer and What Does It Lack? Acta Universitatis Sapientiae, Philologica, $8(2), 123-137$.

Eshghinejad, S. (2016). EFL students' attitudes toward learning English language: The case study of Kashan University students. Cogent Education, 3(1).

Gardner, R. C., \& Lambert, W. E. (1972). Attitudes and Motivation in Second-Language Learning. Rowley, Mass: Newbury House Publishers.

Hoover, W. (1982). Language and literacy learning in bilingual education: Preliminary report. Cantonese site analytic study. Austin, TX: Southwest Educational Development Laboratory.

Krista, B., \& Casey, L. (2013). Bilingualism in the Early Years: What the Science Says (pp. 67-92).

Jean-Mark, D. (2015). Bilingualism and Multilingualism (pp. 56-79).

Latham, A. S. (1998). The Advantages of Bilingualism. Educational Leadership, 56(3), 79-80.

Lydiah, K. K. (2015). Classroom discourse in Bilingual and Multilingual Kenyan Primary Schools (pp. 34-82).

Inal, S., Evin, İ.,\&Saracaoğlu, A.S.(2005).The relation between students' attitudes toward foreign language and foreign language achievement. Language Journal, 130, 37-52.

Suni, M., \& Latomaa, S. (2012). Dealing with Increasing Linguistic Diversity in Schools - the Finnish Example. In J. Blommaert, S. Leppänen, P. Pahta, \& T. Räisänen (Eds.), Dangerous Multilingualism (pp. 67-95). Basingstoke: Palgrave Macmillan UK. https://doi.org/10.1057/9781137283566_4

Salim, A., \& Ekatrina, S. (2010). Advantages of Bilinguals Over Monolinguals in Learning a Third Language. Journal of Psycholinguistic Research, 31(6).

Shams, M. (2008). Students' attitudes, motivation and anxiety towards English language learning. Journal of Research, 2, 121-144.

Roos R. (1990). Language attitudes in the second language situation. Per Linguam A Journal of Language Learning, 6(2).

Tosuncuoglu, I. (2017). ECRIF Framework System. Journal of Education and Training Studies, 5(3), 130-134. https://doi.org/10.11114/jets.v5i3.2175

Yüksek, S. S. (2003). Bilingualism and attitudes towards foreign language learning, Unpublished master's thesis, Institute of Social science Department of English Language Teaching, Mersin, Turkey.

Appendix 1. Opinions about second language learning

\begin{tabular}{|c|c|c|c|c|c|c|c|c|c|c|}
\hline & Grup & $\mathrm{N}$ & $\overline{\mathrm{X}}$ & $\mathrm{sd}$ & $S e_{X}$ & t Test & & & \multirow{2}{*}{\multicolumn{2}{|c|}{ Diff. }} \\
\hline & & & & & & $\mathrm{t}$ & $\mathrm{df}$ & $\mathrm{p}$ & & \\
\hline \multirow{2}{*}{$\begin{array}{l}\text { 1- The people who speak a language best are those } \\
\text { who know only one language rather than two or } \\
\text { more. }\end{array}$} & BAU & 196 & 2,60 & 1,13 & 08 & \multirow[b]{2}{*}{ 63 } & \multirow[b]{2}{*}{366} & \multirow[b]{2}{*}{, 532} & & \\
\hline & AYU & 172 & 2,52 & 1,12 & 09 & & & & & \\
\hline \multirow{2}{*}{ 2- Native speakers make the best language teachers. } & BAU & 196 & 2,93 & 1,06 & 08 & \multirow{2}{*}{$-5,01$} & \multirow{2}{*}{352} & \multirow{2}{*}{, 000} & AYU & \\
\hline & AYU & 172 & 3,51 & 1,14 &, 09 & & & & BAU & \\
\hline \multirow{2}{*}{$\begin{array}{l}\text { 3- You should try not to use your first language } \\
\text { while you are learning another language. }\end{array}$} & BAU & 196 & 2,76 & 1,14 &, 08 & \multirow{2}{*}{$-2,273$} & \multirow{2}{*}{349} & \multirow{2}{*}{024} & AYU & \\
\hline & AYU & 172 & 3,04 & 1,25 &, 10 & & & & BAU & \\
\hline \multirow{2}{*}{$\begin{array}{l}\text { 4- It is important not to have an accent in another } \\
\text { language. }\end{array}$} & BAU & 195 & 2,86 & 1,01 & 07 & \multirow{2}{*}{$-5,79$} & \multirow{2}{*}{343} & \multirow{2}{*}{, 000} & AYU & \\
\hline & AYU & 172 & 3,52 & 1,16 & 09 & & & & BAU & \\
\hline 5- Switching between languages in a conversation is & BAU & 194 & 3,20 & 1,19 & 09 & 1,12 & 364 & ,263 & & \\
\hline
\end{tabular}




\begin{tabular}{|c|c|c|c|c|c|c|c|c|c|c|}
\hline rude even if the other person knows both languages. & AYU & 172 & 3,06 & 1,16 & ,09 & & & & & \\
\hline \multirow{2}{*}{$\begin{array}{l}\text { 6- Children learn second languages better than } \\
\text { adults }\end{array}$} & BAU & 187 & 3,15 & 92 & 07 & \multirow{2}{*}{$-10,73$} & \multirow{2}{*}{357} & \multirow{2}{*}{, 000} & \multirow{2}{*}{$\begin{array}{l}\text { AYU } \\
\text { BAU }\end{array}$} & $>$ \\
\hline & AYU & 172 & 4,12 & ,78 & 06 & & & & & \\
\hline \multirow{2}{*}{$\begin{array}{l}\text { 7- People who go to live in a new country should } \\
\text { give up their own language. }\end{array}$} & BAU & 195 & 3,57 & 1,04 & 07 & \multirow{2}{*}{15,08} & \multirow{2}{*}{363} & \multirow{2}{*}{, 000} & BA & $>$ \\
\hline & AYU & 172 & 1,96 & 1,00 & 08 & & & & & \\
\hline \multirow{2}{*}{$\begin{array}{l}\text { 8- It is difficult to learn a second language in a } \\
\text { classroom. }\end{array}$} & BAU & 194 & 2,78 & 1,15 & 08 & \multirow{2}{*}{,- 82} & \multirow{2}{*}{364} & \multirow{2}{*}{,415 } & & \\
\hline & AYU & 172 & 2,87 & 1,04 &, 08 & & & & & \\
\hline
\end{tabular}

Appendix 2. Type of motivation

\begin{tabular}{|c|c|c|c|c|c|c|c|c|c|c|}
\hline & Grup & $\mathrm{N}$ & $\overline{\bar{X}}$ & $\mathrm{Sd}$ & Se⿳亠口⿵冂卄 & t Test & $\mathrm{df}$ & $\mathrm{p}$ & Diff. & \\
\hline \multirow{2}{*}{$\begin{array}{l}\text { 1- Speaking or learning another language is important } \\
\text { to me because it will allow me to be more at ease with } \\
\text { people who speak that language. }\end{array}$} & BAU & 193 & 3.92 & 1.04 & .07 & \multirow[t]{2}{*}{-5.81} & \multirow[t]{2}{*}{351} & \multirow[t]{2}{*}{.000} & \multirow{2}{*}{$\begin{array}{l}\text { AYU } \\
\text { BAU }\end{array}$} & \multirow[t]{2}{*}{$>$} \\
\hline & AYU & 163 & 4.49 & .80 & .06 & & & & & \\
\hline \multirow{2}{*}{$\begin{array}{l}\text { 2- Speaking or learning another language is important } \\
\text { to me only because I need it for my career. }\end{array}$} & BAU & 193 & 4.12 & .89 & .06 & \multirow{2}{*}{8.03} & \multirow{2}{*}{307} & \multirow{2}{*}{.000} & \multirow{2}{*}{$\begin{array}{l}\text { BAU } \\
\text { AYU }\end{array}$} & $>$ \\
\hline & AYU & 163 & 3.25 & 1.12 & .09 & & & & & \\
\hline \multirow{2}{*}{$\begin{array}{l}\text { 3- Speaking or learning another language is important } \\
\text { to me because I will be able to meet and to more kinds } \\
\text { of people. }\end{array}$} & BAU & 193 & 3.86 & 1.01 & .07 & \multirow{2}{*}{-4.62} & \multirow{2}{*}{354} & \multirow{2}{*}{.000} & \multirow{2}{*}{$\begin{array}{l}\text { AYU } \\
\text { BAU }\end{array}$} & $>$ \\
\hline & AYU & 163 & 4.33 & .89 & .07 & & & & & \\
\hline \multirow{2}{*}{$\begin{array}{l}\text { 4- Speaking or learning another language is important } \\
\text { to me because it will make me more knowledgeable. }\end{array}$} & BAU & 193 & 3.92 & 1.00 & .07 & \multirow{2}{*}{-3.93} & \multirow{2}{*}{354} & \multirow{2}{*}{.000} & \multirow{2}{*}{$\begin{array}{l}\text { AYU } \\
\text { BAU }\end{array}$} & $>$ \\
\hline & AYU & 163 & 4.31 & .84 & .07 & & & & & \\
\hline \multirow{2}{*}{$\begin{array}{l}\text { 5- Speaking or learning another language is important } \\
\text { to me because I will be able to enjoy the films and } \\
\text { books of the people who speak it better. }\end{array}$} & BAU & 193 & 3.93 & 1.03 & .07 & \multirow{2}{*}{-6.63} & \multirow{2}{*}{335} & \multirow{2}{*}{.000} & \multirow{2}{*}{$\begin{array}{l}\text { AYU } \\
\text { BAU }\end{array}$} & $>$ \\
\hline & AYU & 163 & 4.53 & .68 & .05 & & & & & \\
\hline \multirow{2}{*}{$\begin{array}{l}\text { 6- Speaking or learning another language is important } \\
\text { to me because I think it will someday be useful in } \\
\text { getting a good job. }\end{array}$} & BAU & 193 & 3.89 & 1.03 & .07 & \multirow{2}{*}{-7.50} & \multirow{2}{*}{338} & \multirow{2}{*}{.000} & \multirow{2}{*}{$\begin{array}{l}\text { AYU } \\
\text { BAU }\end{array}$} & $>$ \\
\hline & AYU & 162 & 4.58 & .69 & .05 & & & & & \\
\hline \multirow{2}{*}{$\begin{array}{l}\text { 7- Speaking or learning another language is important } \\
\text { to me because I will be able to take part more freely in } \\
\text { the activities of other cultural groups. }\end{array}$} & BAU & 193 & 4.02 & .96 & .07 & \multirow{2}{*}{-3.48} & \multirow{2}{*}{354} & \multirow{2}{*}{.001} & \multirow{2}{*}{$\begin{array}{l}\text { AYU } \\
\text { BAU }\end{array}$} & $>$ \\
\hline & AYU & 163 & 4.37 & .92 & .07 & & & & & \\
\hline
\end{tabular}

Appendix 3. Attitudes toward second language learning

\begin{tabular}{|c|c|c|c|c|c|c|c|c|c|c|}
\hline & Grup & $\mathrm{N}$ & $\overline{\mathrm{X}}$ & sd & Sez & $\begin{array}{l}\mathrm{t} \text { Test } \\
\mathrm{t}\end{array}$ & df & $\mathrm{p}$ & Diff. & \\
\hline \multirow{2}{*}{ 1- It is important to be able to speak two languages. } & BAU & 205 & 2.77 & 1.40 & 205 & \multirow{2}{*}{-13.49} & \multirow{2}{*}{342} & \multirow{2}{*}{.000} & \multirow{2}{*}{$\begin{array}{l}\text { AYU } \\
\text { BAU }\end{array}$} & \multirow[t]{2}{*}{$>$} \\
\hline & AYU & 166 & 4.36 & .84 & 166 & & & & & \\
\hline \multirow{2}{*}{ 2- Knowing two languages makes people cleverer. } & BAU & 204 & 3.23 & 1.15 & 204 & \multirow{2}{*}{-9.50} & \multirow{2}{*}{368} & \multirow{2}{*}{.000} & AYU & $>$ \\
\hline & AYU & 166 & 4.26 & .94 & 166 & & & & BAU & \\
\hline \multirow{2}{*}{ 3- Being able to write in two languages is important. } & BAU & 205 & 3.79 & 1.02 & 205 & \multirow{2}{*}{-5.11} & \multirow{2}{*}{369} & \multirow{2}{*}{.000} & AYU & $>$ \\
\hline & AYU & 166 & 4.29 & .84 & 166 & & & & BAU & \\
\hline \multirow{2}{*}{$\begin{array}{l}\text { 4- All school in my country should teach pupils to } \\
\text { speak in two languages. }\end{array}$} & BAU & 205 & 3.92 & .93 & 205 & \multirow{2}{*}{-1.36} & \multirow{2}{*}{369} & \multirow{2}{*}{.174} & & \\
\hline & AYU & 166 & 4.06 & 1.03 & 166 & & & & & \\
\hline \multirow{2}{*}{$\begin{array}{l}\text { 5- Children in my country should learn to read two } \\
\text { languages. }\end{array}$} & BAU & 205 & 3.81 & 1.01 & 205 & \multirow{2}{*}{-1.72} & \multirow{2}{*}{369} & \multirow{2}{*}{.087} & & \\
\hline & AYU & 166 & 4.00 & 1.06 & 166 & & & & & \\
\hline \multirow{2}{*}{$\begin{array}{l}\text { 6- People who speak two languages can have more } \\
\text { friends than those who speak one language. }\end{array}$} & BAU & 205 & 3.30 & 1.20 & 205 & \multirow{2}{*}{-3.42} & \multirow{2}{*}{369} & \multirow{2}{*}{.001} & AYU & $>$ \\
\hline & AYU & 166 & 3.73 & 1.19 & 166 & & & & BAU & \\
\hline \multirow{2}{*}{$\begin{array}{l}\text { 7- People may earn more money if they speak two } \\
\text { languages. }\end{array}$} & BAU & 205 & 3.48 & 1.16 & 205 & \multirow{2}{*}{-4.19} & \multirow{2}{*}{362} & \multirow{2}{*}{.000} & AYU & $>$ \\
\hline & AYU & 166 & 3.96 & 1.07 & 166 & & & & BAU & \\
\hline \multirow[t]{2}{*}{ 8-People know more if they speak two languages. } & BAU & 205 & 3.21 & 1.18 & 205 & \multirow{2}{*}{-8.14} & \multirow{2}{*}{366} & \multirow{2}{*}{.000} & AYU & $>$ \\
\hline & AYU & 164 & 4.13 & .99 & 164 & & & & BAU & \\
\hline
\end{tabular}




\section{Copyrights}

Copyright for this article is retained by the author(s), with first publication rights granted to the journal.

This is an open-access article distributed under the terms and conditions of the Creative Commons Attribution license (http://creativecommons.org/licenses/by/4.0/). 